learned from Joe Kallenbach and are grateful, while we mourn his passing.

Samuel J. Eldersveld

George Grassmuck

University of Michigan

\section{Betty Nesvold}

I am writing with a sense of sorrow and of personal loss, for Betty Nesvold has passed away.

By any measure, Betty Nesvold was remarkable. A mother of five, her life was intimately interwoven with San Diego State University. Two of her children graduated from here as did her husband Al. Betty was too busy raising her brood to focus on her own education, and it wasn't until she was in her early forties that she completed her degree in our department. She decided to join the work force, but was turned down by Ryan Corporation because she could not pass the physical-a trick knee did her in. She returned to San Diego State University for her master's degree, linking up with the Feierabends, who were beginning their path-breaking research on comparative political violence. Her master's thesis was so highly regarded in the discipline that although unpublished it was often cited in the literature. With family in tow, Betty moved on to the University of Minnesota, where she received her doctorate. In 1967, she returned to San Diego State University as an assistant professor. Within the next seven years, Betty became perhaps the most prominent woman in the American Political Science Association, becoming its first woman treasurer in 1974. Betty also served as president of the Western Political Science Association, where she was instrumental in shaking up the ol' boy network and revitalizing this regional association. In addition, Betty was the first woman to be chair of the Inter-University Consortium for Political Research, a founding member and president of the Woman's Caucus of the APSA, as well as founding and heading the Social Science Research and Instructional Council in the California State University system.

At San Diego State University, Betty chaired the Political Science
Department, served as associate dean for the College of Arts and Letters, and was for many years a member of the Woman's Studies Advisory Committee, a program which was close to her heart.

Betty Nesvold was a pioneer. Her early scholarship was on the cutting edge of the discipline; her more recent work on feminist concerns stretched the boundaries on sensitive social issues. She taught and lead by example. She broke down barriers and walked where women had never trod before. For the new generation of women political scientists who follow in her footsteps, there will always be an indebtedness; for Betty Nesvold made it possible.

Lou Terrell

San Diego State University

\section{Thomas C. Wiegele}

A funeral Mass was held Wednesday, August 14, for Thomas C. Wiegele, a well-known Northern Illinois University political science professor and Presidential Research Professor, several days before he planned to retire.

Wiegele, 58, died of an aneurysm just after noon Friday, August 9, at DeKalb's Kishwaukee Community Hospital, according to his son, Edward Wiegele.

Wiegele was considered a pioneer in biosocial research and in electronic voice stress analysis of political leaders during international crises. His research interests also included the impact of biomedical factors on political behavior and international biotechnology policy.

Last year, he received a $\$ 15,000$ grant from the U.S. Institute of Peace to research and write a book, "The Libyan Chemical Weapons Plant Episode." His research in electronically analyzing voice patterns of world leaders won him international attention when, in 1979, he traveled to Moscow to present a paper at the International Political Science Association, detailing his voice stress findings analysis of political leaders during the 1961 Berlin crisis.

His widow, Mary Wiegele, an NIU publications editor, said her husband, in his retirement, was "looking forward to studying photography and Spanish, and he planned to stay active in scholarship." A retirement party was held for him last Wednesday night, less than 48 hours before his death, by colleagues who gathered to honor him at NIU's Social Sciences Research Institute.

Wiegele was born August 18, 1932, in Milwaukee, the son of Joseph and Leone Kohn Wiegele. He served in the U.S. Army during the Korean conflict and received a bachelor's degree from Marquette University, Milwaukee, in 1956. He married Mary Preo in Milwaukee on November 17 the same year.

After college, Wiegele was a high school teacher in Brown Deer, Wisconsin. He later earned master's and $\mathrm{Ph} . \mathrm{D}$. degrees from the University of Pennsylvania, Philadelphia, in 1965 and 1967 , respectively.

Wiegele was a political science faculty member at St. Joseph's College, Philadelphia, 1967-69, and served as a research associate and administrative officer at Penn's Foreign Policy Research Institute, 1965-68. He joined NIU's political science department faculty in 1969.

Wiegele's books included Biopolitics: Search for a More Human Political Science (1979) and Biology and the Social Sciences: An Emerging Revolution (1982), both from Westview Press, Boulder, Colorado. He was a co-author of Leaders Under Stress: A Psychophysiological Analysis of International Crises with Gordon Hilton, Kent Oots and Susan Kisiel, and published by Duke University Press, Durham, North Carolina in 1985. Wiegele also was the author of many journal articles.

"He was a very important member of our faculty," said Lettie Wenner, chair of Northern's political science department. "It's a terrible loss to us. We were hoping that he'd be able to stay on as an emeritus professor and guide graduate students. His great contribution was the creation of our biopolitics program."

Wenner notes that Wiegele was one of the first to work in the new field of biosocial research. He was director of NIU's Program for Biosocial Research, and also was one of the founding members of the Association for Politics and the Life Sciences, an international society. Wiegele served as APLS executive 
director for more than 10 years, and he also edited the society's journal, Politics and the Life Sciences.

Wenner adds that the American Political Science Association had planned to honor Wiegele at their conference in Washington, D.C. at the end of the month. "Now I guess it will be a memorial service," she observed.

Wiegele in 1987 was one of two NIU full professors named as Presi- dential Research Professors. The prestigious professorships are intended to allow honorees to conduct programs of research or creative work over a four-year period, supported by special stipends. At the end of the four-year period, recipients have the title, Distinguished Research Professor.

Besides his widow, Wiegele is survived by three sons: Joseph, Peachtree, Georgia; Edward, Houston,
Texas; and Thomas, Schaumburg; two daughters: Madelynn Herman of Chula Vista, California; and Katharine Wiegele, DeKalb; as well as six grandchildren.

Also, a brother, Noel Wiegele of Mequon, Wisconsin; a sister, Kathleen Thompson, Claremont, New Hampshire; an aunt, Anita Kohn of Peoria, Arizona; and several nieces and nephews. He was preceded in death by his parents. 